\title{
Exercise partially reverses the inhibitory effect of caffeine on liver gluconeogenesis in type 1 diabetic rats with hypoglycemia
}

\author{
EH Gilglioni ${ }^{1}$, CM Ghuidotti ${ }^{2}$, VR Vilela ${ }^{1}$, C Bataglini $^{2}$, JP Furlan ${ }^{3}$, JA Berti ${ }^{2}$, \\ MMD Pedrosa ${ }^{2}$, VAF Godoi ${ }^{2}$ \\ ${ }^{1}$ Department of Biochemistry, State University of Maringá, Maringá, Paraná, Brazil \\ ${ }^{2}$ Department of Physiological Sciences, State University of Maringá, Maringá, Paraná, Brazil \\ ${ }^{3}$ Department of Physical Education, State University of Maringá, Maringá, Paraná, Brazil
}

Received: October 5, 2015

Accepted: May 29, 2016

\begin{abstract}
The purpose was to determine the possible effects of exercise and/or caffeine on hypoglycemia and liver gluconeogenesis in diabetic rats. These were divided into four subgroups: (a) intraperitoneal insulin only, (b) exercise bout before insulin, (c) caffeine after insulin, and (d) exercise bout before and caffeine after insulin. The marked glycemic drop $45 \mathrm{~min}$ after insulin $(0 \mathrm{~min}=229.00,45 \mathrm{~min}=75.75)$ was considerably reduced $(p<$ 0.05 ) by caffeine or exercise ( $45 \mathrm{~min}$ : exercise $=127.00$, caffeine $=104.78)$. However, this systemic effect was lost $(p>0.05)$ when they were combined $(45 \mathrm{~min}$ : exercise + caffeine $=65.44)$ (Mean, in $\left.\mathrm{mg} \cdot \mathrm{dL}^{-1}\right)$. Caffeine alone strongly inhibited liver glucose production from $2 \mathrm{mM}$ lactate $45 \mathrm{~min}$ after insulin (without caffeine $=3.05$, with caffeine $=0.27 ; p<0.05$ ), while exercise + caffeine partially re-established the liver gluconeogenic capacity (exercise + caffeine $=1.61 ; p<0.05$ relative to the other groups) (Mean, in $\mu \mathrm{mol} \cdot \mathrm{g}^{-1}$ ). The improved hypoglycemia with caffeine or exercise cannot be explained by their actions on liver gluconeogenesis. As their beneficial effect disappeared when they were combined, such association in diabetic patients should be avoided during the period of hyperinsulinemia due to the risk of severe hypoglycemia.
\end{abstract}

Keywords: exercise, caffeine, type 1 diabetes, insulin, rats, liver

\section{Introduction}

The maintenance of glycemia is a finely tuned mechanism that demands the integration of glucose absorption, production, and uptake (30), as well as the presence of signaling molecules such as insulin, glucagon, adrenaline, adenosine, and others (13). The liver is a multifunctional organ with an active role on this process, operating as a glycemic buffer by promoting synthesis/degradation of the glycogen store as well as synthesizing new glucose molecules (gluconeogenesis) (31). These metabolic pathways are constantly modulated by many factors, such as nutritional condition and physical activity (5).

The metabolic disorder resulting from lack of insulin is known as type 1 diabetes mellitus (T1DM) $(11,32,39)$. It is characterized by an unbalanced increase in glycemia that demands the use of exogenous insulin to normalize the blood glucose levels and preserve homeostasis.

Corresponding author: Prof. Maria Montserrat D. Pedrosa, PhD

Department of Physiological Sciences, State University of Maringá

Av. Colombo, 5790, Jardim Universitário, Maringá, Paraná 87020-900, Brazil

Phone: +55 443011 4698; Cellular phone: +55 449116 2280; E-mail: montserratfurlan@gmail.com 
Many T1DM patients are young and physically active, and exercise in T1DM can trigger adverse effects such as hypoglycemia and hyperglycemia. More than $30 \%$ of children and youngsters with T1DM show hypoglycemic episodes during an exercise session. On the other hand, hyperglycemia disrupts the metabolic and vascular benefits of exercise (20). Despite an intense and rigorous glycemic control preventing the secondary complications of diabetes, there is an intrinsic inability in regulating glucose concentration during and after exercise. In addition, nocturnal hypoglycemia is common in T1DM on the night following exercise and, as in a vicious cycle, the response to exercise on the following session is impaired (10).

There are many substances that interfere with the glycemic control, such as caffeine (1,3,7-trimethylxanthine), found in products widely consumed such as coffee, tea, guarana, chocolate, and medications $(3,16,28,47)$. Caffeine is avoided in some cases, such as autosomal dominant polycystic kidney disease, due to prior awareness of the patients of need for restriction, because caffeine may induce cyst and kidney enlargement (45). However, in other cases, in spite of not having nutritional value, caffeine has been used as an ergogenic substance because it improves performance in long-term physical activities. The ergogenic effect of caffeine is reversible and seems to be mediated by central and peripheral mechanisms of action that can trigger physiological and metabolic changes (19, 38, 40, 44). At first, the action of caffeine was linked to an increase in the serum concentration of adrenaline and noradrenaline, which would lead to the enhanced oxidation of free fatty acids and saving of glycogen by the muscle tissue $(9,19,25,38,40,44)$, but adenosine receptor antagonism seems to be the major mechanism of action of caffeine (4).

Adenosine is a ubiquitous cellular constituent released from the hydrolysis of adenosine triphosphate (ATP) in the extracellular space or intracellularly; the newly formed adenosine is exported to the extracellular space by specific nucleoside transporters $(12,22,49)$. In the extracellular space, adenosine can bind to four different G-protein coupled receptors. The A1 and A3 receptors inhibit adenylyl cyclase, while the A2a and A2b receptors activate the enzyme (43). In the liver, the adenosine receptors can have many roles concerning glucose metabolism regulation, lipolysis, and inflammation $(23,37,48)$. An increase in the expression of these receptors in the liver in adverse conditions like diabetes could link their activities with the pathogenesis of liver complications in $\operatorname{T1DM}(7,15,21,29)$. In addition, situations that increase the levels of ATP hydrolysis, such as exercise and T1DM, are accompanied by increased levels of adenosine $(10,35)$. This study assessed the in vivo glycemic response of T1DM rats made hypoglycemic by insulin injection, as well as their liver gluconeogenic activity, in the presence of exercise, and/or caffeine. The purpose was to determine the possible synergistic or antagonistic effects of these agents on the drop and recovery of glycemia. Particularly, in situ liver perfusion assessed the liver contribution to the glycemic response observed. Exercise and caffeine both had a beneficial effect on the glycemic profile of T1DM rats during the hypoglycemic episode. However, when combined, these effects disappeared. In addition, the in vivo glycemic profile could not be readily explained by the observed liver gluconeogenesis, indicating that the systemic effects of exercise and caffeine are much more complex than their hepatic effects.

\section{Materials and Methods}

\section{Materials}

Regular human insulin $\left(\right.$ Novolin $\left.^{\circledR}\right)$ was obtained from Novo Nordisk (Brazil). Alloxan was obtained from Sigma (Brazil). All other chemicals used had high degree of purity. 


\section{Animals}

All experimental procedures were approved by The University of Maringá Ethics Committee (CEAE no. 002/2010 and CEAE no. 069/2013). Male Wistar rats (Rattus norvegicus) weighing $180 \mathrm{~g}$ and aging 59 days were kept at the animal house of the Department of Physiological Sciences under controlled temperature $\left(23^{\circ} \mathrm{C}\right)$ and photoperiod $(12 \mathrm{~h} \mathrm{light} / 12 \mathrm{~h}$ dark). Water and balanced Nuvital ${ }^{\circledR}$ chow were given freely until the day before the experiment, when the chow was removed, so that the animals had a $14 \mathrm{~h}$ fasting (overnight) at the beginning of the experimental protocols. For the in vivo experiments, the animals remained under fasting until the end of the protocols, when they were returned to their cages.

\section{Diabetes induction}

The animals were given an intravenous injection of alloxan $\left(40 \mathrm{mg} \cdot \mathrm{kg} \cdot \mathrm{bw}^{-1}\right)$. After 4 days, the glycemia during the fasted state was checked through the caudal vein using glucose test strips and a glucometer (Optium Xceed). All animals having fasting blood glucose values $\geq 200 \mathrm{mg} \cdot \mathrm{dL}^{-1}$ were included in the study. The experimental protocols were carried out on the following day.

\section{Experimental groups}

For both the in vivo and in situ experiments, the type 1 diabetic animals (T1DM) were divided into four subgroups. Those receiving insulin injection (T1DM+I), those subjected to an acute exercise bout before insulin injection (T1DM+E+I), those given caffeine 15 min after insulin injection (T1DM+I+C), and those subjected to an acute exercise bout before and given caffeine $15 \mathrm{~min}$ after insulin injection $(\mathrm{T} 1 \mathrm{DM}+\mathrm{E}+\mathrm{I}+\mathrm{C})$.

\section{Exercise bout}

The exercise bout (groups $\mathrm{T} 1 \mathrm{DM}+\mathrm{E}+\mathrm{I}$ and $\mathrm{T} 1 \mathrm{DM}+\mathrm{E}+\mathrm{I}+\mathrm{C}$ ) consisted of a run in a programmed treadmill (KT3000, Ibramed, Brazil), adapted for training rats. The animals did not have an adaptation period before the experiments. Initial treadmill speed was $0.5 \mathrm{~km} \cdot \mathrm{h}^{-1}$, with progressive increases of $0.2 \mathrm{~km} \cdot \mathrm{h}^{-1}$ every $2 \mathrm{~min}$, until exhaustion, characterizing an acute exercise bout. Exhaustion was determined through visual observation and defined as the moment when the animal could not keep up with the treadmill speed. Insulin was given immediately after exhaustion.

\section{Insulin-induced hypoglycemia (IIH)}

Hypoglycemia was induced in all the groups through intraperitoneal (ip.) injection of regular, fast-acting insulin $\left(1 \mathrm{U} \cdot \mathrm{kg} \cdot \mathrm{bw}^{-1}\right)$. The glycemia of the animals was recorded through the caudal vein using glucose test strips and a glucometer (Optium Xceed) during $5 \mathrm{~h}$ after insulin injection (times $0,15,30,45,60,120,180$, and $300 \mathrm{~min}$ ). The values were expressed as $\mathrm{mg} \cdot \mathrm{dL}^{-1}$.

\section{Caffeine administration}

Caffeine was administered orally (gavage) at a dose of $5 \mathrm{mg} \cdot \mathrm{kg} \cdot \mathrm{bw}^{-1} 15 \mathrm{~min}$ after the ip. injection of regular insulin (T1DM+I+C and T1DM+E+I+C), while the other groups were given an equivalent volume of saline.

\section{In situ liver perfusion}

The perfusion system is composed of vessels for the perfusion fluid, a peristaltic pump and a membrane oxygenator, coupled to a water bath with external circulation of warm water and a 
cylinder of carbogenic mixture $\left(\mathrm{O}_{2} / \mathrm{CO}_{2}=95 / 5 \%\right)$. The perfusion fluid used was KrebsHenseleit-bicarbonate $(\mathrm{KH})$ with $\mathrm{pH} 7.4$ at $37{ }^{\circ} \mathrm{C}$. Forty-five minutes after insulin injection (the time of the lowest glycemia of the T1DM+I group, see Fig. 2), animals were ip. anesthetized with sodium pentobarbital $\left(40 \mathrm{mg} \cdot \mathrm{kg} \cdot \mathrm{bw}^{-1}\right)$ and subjected to laparotomy. The portal vein was cannulated under low flux $\left(1 \mathrm{~mL} \cdot \mathrm{min}^{-1} \cdot \mathrm{g}^{-1}\right)$ and another cannula was inserted into the inferior cava vein to allow the rapid exsanguination of the liver while the flux was elevated to about $4 \mathrm{~mL} \cdot \mathrm{min}^{-1} \cdot \mathrm{g}^{-1}$ to assure an adequate supply of oxygen to the organ. After 30 min of perfusion for the stabilization of the preparation, samples of the effluent fluid were collected each $5 \mathrm{~min}$ for further biochemical assays. During the first $10 \mathrm{~min}$ of collection, the perfusion was made with $\mathrm{KH}$ alone and then L-lactate was added to the $\mathrm{KH}$ as gluconeogenic precursor for $20 \mathrm{~min}$, at a concentration of $2 \mathrm{mM}$, a near-physiological blood value during fasting (2).

Demonstrative experiment for the calculation of the area under the curve

After a perfusion period of $10 \mathrm{~min}$ (basal glucose production), L-lactate was dissolved in the perfusion fluid and perfused from the 10th to the 30th min. Samples of the effluent fluid were collected at 5-min intervals and the glucose concentrations were determined (6). The difference in the glucose production during the perfusion with L-lactate and the basal glucose production was used to calculate the area under the curve (AUC), whose value was expressed in $\mu \mathrm{mol} \cdot \mathrm{g}^{-1}$ liver (Fig. 1). The AUCs in Fig. 3 and Table I were obtained from similar procedures.

Determination of glucose and pyruvate in the perfusate

Glucose was measured by the glucose-oxidase method (6) and pyruvate by a previously described technique (8). The values of glucose and pyruvate in the perfusate samples were expressed in $\mu \mathrm{mol} \cdot \mathrm{min}^{-1} \cdot \mathrm{g}^{-1}$ liver.

\section{Statistical Analysis}

The results [mean \pm standard deviation (SD) of 6-10 experiments per group] were assessed through student's $t$-test, using the T1DM+I as the reference group, with the software GraphPad Prism 5.0. The significance level was set at 5\%.

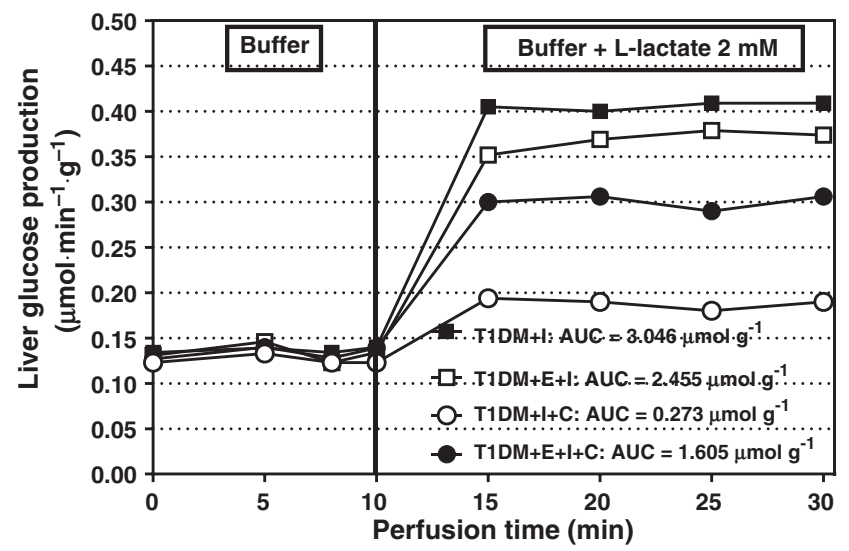

Fig. 1. Demonstrative experiment of the glucose production $\left(\mu \mathrm{mol} \cdot \mathrm{min}^{-1} \cdot \mathrm{g}^{-1}\right)$ from $2 \mathrm{mM}$ L-lactate in liver perfusion of $\mathrm{T} 1 \mathrm{DM}+\mathrm{I}, \mathrm{T} 1 \mathrm{DM}+\mathrm{E}+\mathrm{I}$, $\mathrm{T} 1 \mathrm{DM}+\mathrm{I}+\mathrm{C}$, and $\mathrm{T} 1 \mathrm{DM}+\mathrm{E}+\mathrm{I}+\mathrm{C}$ rats. The data are of one animal of each group 
Table I. Liver pyruvate production from $2 \mathrm{mM} \mathrm{L}$-lactate in T1DM+I, T1DM+E+I, T1DM+I+C, and T1DM+E+I+C rats. The AUCs are expressed in $\mu \mathrm{mol} \cdot \mathrm{g}^{-1}$ liver as mean $\pm \mathrm{SD}$ of six to eight perfusion experiments

\begin{tabular}{|l|c|}
\hline Group & Pyruvate production $\left(\mu \mathbf{m o l}^{\left.-\mathbf{g}^{-1}\right)}\right.$ \\
\hline T1DM+I & $4.97 \pm 0.38$ \\
\hline T1DM+E+I & $6.68 \pm 0.39^{*}$ \\
\hline T1DM+I+C & $6.06 \pm 0.43^{*}$ \\
\hline T1DM+E+I+C & $4.86 \pm 0.30$ \\
\hline
\end{tabular}

${ }^{*} p<0.05$ vs. T1DM+I

\section{Results}

The values of the fasting glycemia were similar across all the experimental groups. The T1DM animals previously subjected to exercise had a tendency of having a higher glycemia than those non-exercised; however, differences were not statistically significant (time 0 min, Fig. 2). In these same groups, the pre- and post-exercise glycemia were not statistically different either ( $p>0.05$ not shown). The time to exhaustion was similar in all the exercised groups and was of $8 \mathrm{~min} 20 \mathrm{~s}$ on average.

Figure 2 shows that soon after insulin injection hypoglycemia was established in all groups and reached the lowest values within the first $45 \mathrm{~min}$. The diabetic group (T1DM+I) did not recover glycemia until time $300 \mathrm{~min}$. However, exercise prior to insulin injection reduced the intensity of the hypoglycemic episode since time $15 \mathrm{~min}$. The administration of caffeine resulted in a better hypoglycemic profile at times 30 and 45 min and better glycemia recovery at $300 \mathrm{~min}$. On the other hand, the association of exercise and caffeine $(\mathrm{T} 1 \mathrm{DM}+\mathrm{E}+\mathrm{I}+\mathrm{C})$ resulted in a severe hypoglycemic crisis after $45 \mathrm{~min}$, similar to the group given only insulin (T1DM+I). Nevertheless, it did not interfere with the capacity of glycemia recovery observed at $300 \mathrm{~min}$. Therefore, exercise, caffeine, and the combination of both promoted a significant recovery at $300 \mathrm{~min}$.

Considering that the hypoglycemic profile was attenuated by either exercise or caffeine, but not their association, a possible effect of the treatments on the liver glucose metabolism was investigated through the in situ liver perfusion. As the lowest glycemic values were found $45 \mathrm{~min}$ after insulin injection, this time was chosen for the liver experiments (Fig. 3, Table I).

As for the liver glucose production from L-lactate (Fig. 3), it was observed that the previous exercise bout did not change this pathway $(p>0.05)$. However, liver

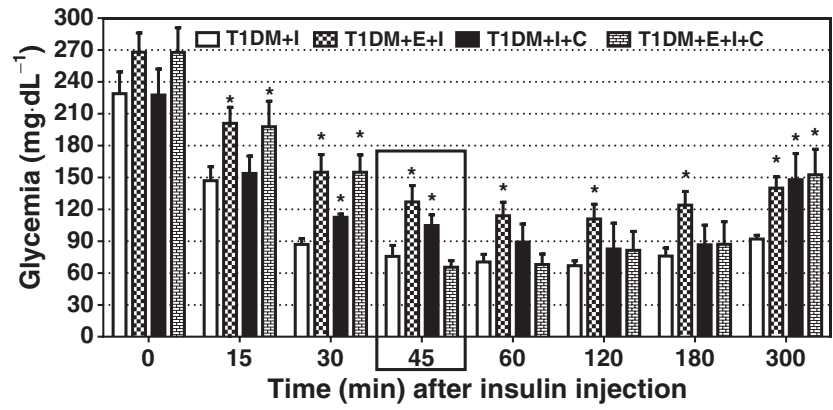

Physiology International (Acta Physiologica Hungarica) 103, 2016
Fig. 2. Glycemic response during IIH. The bars represent the mean \pm SD of six to eight experiments. $* p<0.05$ vs. T1DM+I at each time 


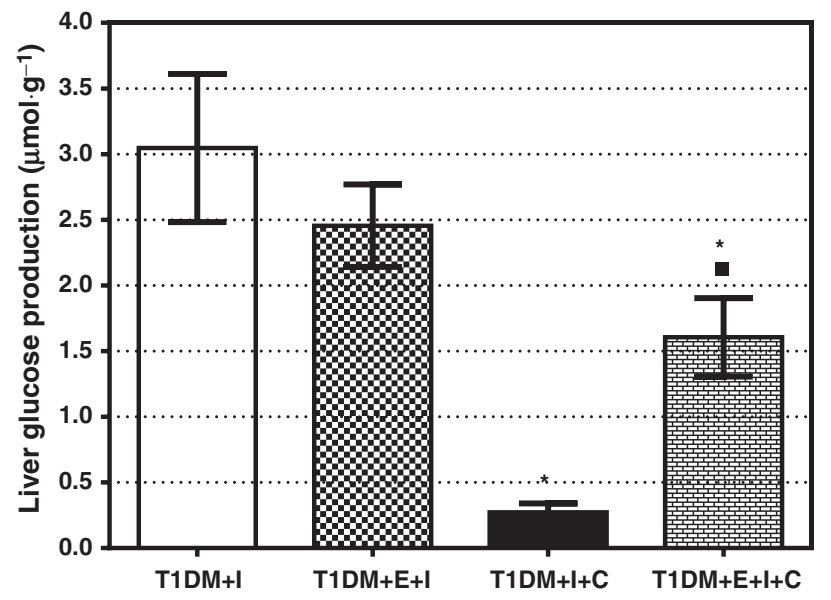

Fig. 3. Liver glucose production from $2 \mathrm{mM}$ L-lactate in T1DM+I, $\mathrm{T} 1 \mathrm{DM}+\mathrm{E}+\mathrm{I}, \mathrm{T} 1 \mathrm{DM}+\mathrm{I}+\mathrm{C}$, and $\mathrm{T} 1 \mathrm{DM}+\mathrm{E}+\mathrm{I}+\mathrm{C}$ rats. The AUCs are expressed in $\mu \mathrm{mol} \cdot \mathrm{g}^{-1}$ liver as mean

$\pm \mathrm{SD}$ of six to eight perfusion experiments. $* p<0.05$ vs. T1DM+I, " $p<0.05$ vs. T1DM+I+C

gluconeogenesis was about 10 times lower in the presence of caffeine. Importantly, it was also observed that the association of exercise and caffeine partially re-established the liver capacity of producing glucose from lactate.

As L-lactate is oxidized to pyruvate to be converted to glucose, the liver production of pyruvate from L-lactate was also measured in the perfused liver (Table I). It was observed that in the presence of exercise or caffeine, there were higher pyruvate values than on the other treatments.

\section{Discussion}

The in vivo results showed that insulin-injected T1DM rats had a hypoglycemic episode that did not recover completely after $300 \mathrm{~min}$ (Fig. 2, group T1DM+I).

Since exercise and insulin alone cause an amplifying effect on the number of active GLUT4, which intensifies the glucose use by the skeletal muscle cells $(33,34)$, it was expected that their combination would worsen the hypoglycemia. However, the association of insulin and exercise (Fig. 2, group T1DM+E+I) prevented the lowering of the glycemia to the values of the T1DM+I group. This observation can be explained by the fact that exercise also increases the release of catecholamines, which cause liver gluconeogenesis and glucose release and stimulates lipolysis and the release of free fatty acids in the adipose tissue (17). This scenario demonstrates that exercise could prevent a more severe hypoglycemia and have an important role in the glycemic control in T1DM.

On the other hand, caffeine caused a less pronounced drop of the glycemic level at 30, 45, and $300 \mathrm{~min}$ (group T1DM+I+C, Fig. 2), but it was not different from the T1DM+I group from 60 to $180 \mathrm{~min}$, i.e., caffeine demonstrated a biphasic effect, an acute effect at 30 and $45 \mathrm{~min}$ (higher blood insulin), and a long-term effect at $300 \mathrm{~min}$ (after blood insulin dissipation). The antagonistic effects of caffeine on the adenosine receptors are its major mechanism of action (4). These receptors are found in muscle, liver, and adipose tissue, all of them heavily involved in blood glucose homeostasis. In adipose tissue (A1-subtype receptors), caffeine could result in increased lipolysis and a glucose-saving systemic effect $(3,19,24,25,27,38)$; however, by antagonizing adenosine receptors on skeletal muscle (also A1-subtype receptors), caffeine increases glycolysis (27). In addition, adenosine receptors in 
the liver stimulate gluconeogenesis, glycogenolysis, and glucose release $(14,15,18,21,27$, 36), all of which could be potentially antagonized by caffeine.

Although caffeine also stimulates the release of catecholamines, the dose should be at least 20 times greater than that used in these experiments (47). It seems that at the dose of caffeine employed $\left(5 \mathrm{mg} \cdot \mathrm{kg} \cdot \mathrm{bw}^{-1}\right)$, there is a predominance of the antagonistic effect on the adenosine receptors. This adenosine antagonism by caffeine is the sum of all its effects on many tissues, and may be dependent, among other things, on the relative amount of muscle resulting in glucose consumption - and fat - resulting in glucose sparing (25), in addition to its effects on the liver.

The possibilities listed could result in the less severe hypoglycemic profile of the $\mathrm{T} 1 \mathrm{DM}+\mathrm{E}+\mathrm{I}$ and $\mathrm{T} 1 \mathrm{DM}+\mathrm{I}+\mathrm{C}$ groups. Within this reasoning, we can argue that exercise and caffeine efficiently antagonized hypoglycemia and decreased the glycemic drop, especially during the first $45 \mathrm{~min}$ after insulin injection, leading to a less marked hypoglycemic profile.

On the other hand, the association of exercise and caffeine (Fig. 2, T1DM+E+I+C) caused a glycemic drop similar to insulin (group T1DM+I) between 45 and $180 \mathrm{~min}$. In this case, caffeine may have progressively inhibited the effect of exercise on the muscle cells, so that from 45 to $180 \mathrm{~min}$, the anti-hypoglycemic effects of exercise were completely overcome by caffeine. This may have been caused by caffeine competitively inhibiting the binding of extracellular adenosine with its membrane receptors, which would tend to increase glycolysis and glucose uptake in muscle cells and decrease glucose production and release from the liver (10, 17, 24, 35, 42).

However, both exercise and caffeine, either isolated or associated, had a residual effect and markedly recovered the glycemia after insulin disappearance (Fig. 2, $300 \mathrm{~min}$ ), probably but not exclusively due to an increased lipolysis powered by caffeine and exercise-derived catecholamines $(26,38,41,46)$. It seems that both exercise and/or caffeine are effectively acting as long-term counter-regulatory mechanisms, as judged from the improved glycemia (compared to group T1DM+I) 300 min after insulin injection.

In non-diabetic animals, differently from the T1DM animals, the hypoglycemic profile is not changed by either exercise or caffeine; instead, their association results in a better hypoglycemic profile (4). This difference is most certainly due to the diabetic condition of the animals in this study, because diabetes changes the signaling capacities of many substances (such as exercise-derived catecholamines and adenosine) on the major tissues involved in the response to hypoglycemic conditions, i.e., skeletal muscle, liver, and adipose tissue.

The conversion of L-lactate to pyruvate is the crucial step for L-lactate to be used as gluconeogenic precursor. Liver pyruvate production (Table I) had a qualitative resemblance to the in vivo glycemic profile of the groups $45 \mathrm{~min}$ after insulin injection: lower values in the $\mathrm{T} 1 \mathrm{DM}+\mathrm{I}$ and T1DM+E+I+C groups and higher values in the T1DM+E+I and T1DM+I+C groups. Although the groups have shown increased production of pyruvate, the production of glucose was reduced in the groups T1DM+I+C and T1DM+E+I+C (Fig. 3). It is possible that, in these groups, pyruvate was being diverted to some other cellular pathway, such as that of nitrogen rescue. Therefore, further studies are needed to substantiate these results.

Exercise $(\mathrm{T} 1 \mathrm{DM}+\mathrm{E}+\mathrm{I})$ did not significantly change the liver gluconeogenic capacity from L-lactate during hypoglycemia when compared to the T1DM+I group (Fig. 3). As the hypoglycemic profile of these two groups were significantly different at $45 \mathrm{~min}$ of the IIH the time chosen to assess liver gluconeogenesis - the liver glucose production from L-lactate cannot account for the difference observed in vivo. In this case, the extra-hepatic effects of exercise discussed above predominate over the liver effects, and manifest as variation in blood glucose levels. 
On the other hand, caffeine $(\mathrm{T} 1 \mathrm{DM}+\mathrm{I}+\mathrm{C})$ caused a marked reduction of the liver glucose production from L-lactate. It is possible that caffeine efficiently blocked the liver adenosine receptors $(7,44)$, making way to an enhancement of the inhibitory effect of insulin on the liver glucose production. This suggestion is consistent with the inhibition of A3-subtype receptors $(8,29)$ and with the results of the in situ liver perfusion for the T1DM+I+C group (Fig. 3). However, as hypoglycemia was less severe with caffeine 45 min after insulin injection, extra-hepatic effects were probably predominant. When exercise and caffeine were associated (group T1DM+E+I+C, Fig. 3), liver glucose production was partially restored. Exercise promotes catecholamine release and increased levels of endogenous adenosine $(1,5,10)$, both of which could have partially overcome the inhibitory effect of caffeine on liver gluconeogenesis from L-lactate.

\section{Conclusions}

In summary, the correlation of the liver glucose production from L-lactate with the hypoglycemic profile of the diabetic animals shows that the systemic effects of exercise and caffeine are much more complex than their hepatic effects, so that the in vivo glycemic profile cannot be readily explained by the observed liver gluconeogenesis. This suggests that the systemic effects of exercise and caffeine on the glycemic levels are also dependent upon their actions on other important targets, such as skeletal muscle and adipose tissue. Finally, both exercise and caffeine have a beneficial effect on the glycemic profile of T1DM rats during the decay phase hypoglycemic episode. However, when combined, these effects disappear and therefore the association of exercise and caffeine in T1DM should be avoided during the period of hyperinsulinemia due to the risk of severe hypoglycemia.

\section{Acknowledgements}

This work was supported by CNPq (Grant no. 563870/2010-9), Araucaria Foundation, and CAPES. The experiments were conceived, designed, and performed by E.H. Gilglioni, C.M. Ghuidotti, V.R. Vilela, J.A. Berti, and V.A.F. Godoi. Data analyses and manuscript preparation were performed by M.M.D. Pedrosa, V.A.F. Godoi, and J.P. Furlan.

\section{REFERENCES}

1. Afonso M, de Souza CN, Zagatto AM, Luciano E: Respostas metabólicas agudas ao exercício moderado em ratos wistar (Metabolic response to acute physical exercise in Wistar rats). Motriz 9, 87-92 (2003)

2. Albuquerque GG, Gazola VAFG, Garcia RF, Souza KLA, Barrena HC, Curi R, Bazotte RB: Gluconeogenesis and ketogenesis in perfused liver of rats submitted to short-term insulin-induced hypoglycaemia. Cell Biochem. Funct. 26, 228-232 (2008)

3. Altimari LR, de Moraes AC, Tirapegui J, Moreau RLM: Cafeína e performance em exercícios anaeróbios (Caffeine and performance in anaerobic exercise). Rev. Bras. Ciênc. Farm. 42, 17-27 (2006)

4. Babata LKB, Malta A, Godoi VAF, Pedrosa MMD: Acute exercise and caffeine improve insulin-induced hypoglycemia in normal and malnourished rats. Acta Sci. Biol. Sci. 37, 123-130 (2015)

5. Berglund ED, Lee-Young RS, Lustig DG, Lynes SE, Donahue EP, Camacho RC, Meredith ME, Magnuson MA, Charron MJ, Wasserman DH: Hepatic energy state is regulated by glucagon receptor signaling in mice. J. Clin. Invest. 119, 2412-2422 (2009)

6. Bergmeyer HU, Bernt E (1974): Determination of glucose with glucose-oxidase and peroxidase. In: Methods of Enzymatic Analysis, ed Bergmeyer HU, Verlag Chemie, Academic Press, Weinheim, New York and London, pp. $1205-1215$ 
7. Crist GH, Xu B, Lanoue KF, Lang CH: Tissue-specific effects of in vivo adenosine receptor blockade on glucose uptake in Zucker rats. FASEB J. 12, 1301-1308 (1998)

8. Czok R, Lamprecht W (1974): Pyruvate, phosphoenolpyruvate and glycerate-2-phosphate. In: Methods of Enzymatic Analysis, ed Bermeyer HU, 3rd ed., Academic Press, New York and London, pp. 1446-1448

9. Davis JK, Green JM: Caffeine and anaerobic performance: ergogenic value and mechanisms of action. Sports Med. 39, 813-832 (2009)

10. Davis JM, Zhao Z, Stock HS, Mehl KA, Buggy J, Hand GA: Central nervous system effects of caffeine and adenosine on fatigue. Am. J. Physiol. Regul. Integr. Comp. Physiol. 284, 399-404 (2003)

11. DeFronzo RA: Pathogenesis of type 2 diabetes mellitus. Med. Clin. North Am. 88, 787-835 (2004)

12. Eltzschig HK, Abdulla P, Hoffman E, Hamilton KE, Daniels D, Schönfeld C, Löffler M, Reyes G, Duszenko M, Karhausen J, Robinson A, Westerman KA, Coe IR, Colgan SP: HIF-1-dependent repression of equilibrative nucleoside transporter (ENT) in hypoxia. J. Exp. Physiol. 202, 1493-1505 (2005)

13. Enjyoji K, Kotani K, Thukral C, Blumel B, Sun X, Wu Y, Imai M, Friedman D, Csizmadia E, Bleibel W, Kahn $\mathrm{BB}$, Robson SC: Deletion of cd39/entpd1 results in hepatic insulin resistance. Diabetes 57, 2311-2320 (2008)

14. González-Benítez E, Guinzberg R, Díaz-Cruz A, Piña E: Regulation of glycogen metabolism in hepatocytes through adenosine receptors. Role of $\mathrm{Ca} 2+$ and cAMP. Eur. J. Pharmacol. 437, 105-111 (2002)

15. Grden M, Podgorska M, Szutowicz A, Pawelczyk T: Diabetes-induced alterations of adenosine receptors expression level in rat liver. Exp. Mol. Pathol. 83, 392-398 (2007)

16. Greenberg JA, Boozer CN, Geliebter A: Coffee, diabetes, and weight control. Am. J. Clin. Nutr. 84, 682-693 (2006)

17. Greer F, Hudson R, Ross R, Graham T: Caffeine ingestion decreases glucose disposal during a hyperinsulinemic-euglycemic clamp in sedentary humans. Diabetes 50, 2349-2354 (2001)

18. Guinzberg R, Cortés D, Díaz-Cruz A, Riveros-Rosas H, Villalobos-Molina R, Piña E: Inosine released after hypoxia activates hepatic glucose liberation through A3 adenosine receptors. Am. J. Physiol. Endocrinol. Metab. 290, 940-951 (2006)

19. Hadjicharalambous MP, Kilduff LP, Pitsiladis YP: Brain serotonergic and dopaminergic modulators, perceptual responses and endurance exercise performance following caffeine co-ingested with a high fat meal in trained humans. J. Int. Soc. Sports Nutr. 7, 1-10 (2010)

20. Halliwill JR, Buck TM, Lacewell AN, Romero SA: Postexercise hypotension and sustained postexercise vasodilatation: what happens after we exercise? Exp. Physiol. 98, 7-18 (2013)

21. Harada H, Asano O, Hoshino Y, Yoshikawa S, Matsukura M, Kabasawa Y, Niijima J, Kotake Y, Watanabe N, Kawata T, Inoue T, Horizoe T, Yasuda N, Minami H, Nagata K, Murakami M, Nagaoka J, Kobayashi S, Tanaka I, Abe S: 2-Alkynyl-8-aryl-9-methyladenines as novel adenosine receptor antagonists: their synthesis and structure-activity relationships toward hepatic glucose production induced via agonism of the $\mathrm{A}_{2 \mathrm{~B}}$ receptor. J. Med. Chem. 44, 170-179 (2001)

22. Haskó G, Linden J, Cronstein B, Pacher P: Adenosine receptors: therapeutic aspects for inflammatory and immune diseases. Nat. Rev. Drug Discov. 7, 759-770 (2008)

23. Johnston-Cox H, Koupenova M, Yang D, Corkey B, Gokce N, Farb MG, LeBrasseur N, Ravid K: The A2b adenosine receptor modulates glucose homeostasis and obesity. PLoS One 7, e40584 (2012)

24. Johnston KL, Clifford MN, Morgan LM: Coffee acutely modifies gastrointestinal hormone secretion and glucose tolerance in humans: glycemic effects of chlorogenic acid and caffeine. Am. J. Clin. Nutr. 78, 728-733 (2003)

25. Keijzers GB, De Galan BE, Tack CJ, Smits P: Caffeine can decrease insulin sensitivity in humans. Diabetes Care 25, 364-369 (2002)

26. Kjaer M, Kiens B, Hargreaves M, Richter EA: Influence of active muscle mass on glucose homeostasis during exercise in humans. J. Appl. Physiol. 71, 552-557 (1991)

27. Koupenova M, Ravid K: Adenosine, adenosine receptors and their role in glucose homeostasis and lipid metabolism. J. Cell. Physiol. 1-22 (2014)

28. Lane JD, Feinglos MN, Surwit RS: Caffeine increases ambulatory glucose and postprandial responses in coffee drinkers with type 2 diabetes. Diabetes Care 31, 221-222 (2008)

29. Liu IM, Tzeng TF, Tsai CC, Lai TY, Chang CT, Cheng JT: Increase in adenosine A1 receptor gene expression in the liver of streptozotocin-induced diabetic rats. Diabetes Metab. Res. Rev. 19, 209-215 (2003)

30. Mitrakou A, Ryan C, Veneman T, Mokan M, Jenssen T, Kiss I, Durrant J, Cryer P, Gerich J: Hierarchy of glycemic thresholds for counterregulatory hormone secretion, symptoms, and cerebral dysfunction. Am. J. Physiol. 260, 67-74 (1991)

31. Moore MC, Connolly CC, Cherrington AD: Autoregulation of hepatic glucose production. Eur. J. Endocrinol. 138, 240-248 (1998) 
32. Notkins AL: The causes of diabetes. Sci. Am. 241, 62-73 (1979)

33. Ropelle ER, Pauli JR, Carvalheira JBC: Efeitos moleculares do exercício físico sobre as vias de sinalização insulínica (Molecular effects of physical exercise on the insulin-signaling pathways). Motriz 11, 49-55 (2005)

34. Rose AJ, Richter EA: Skeletal muscle glucose uptake during exercise: how is it regulated? Physiology 20, 260-270 (2005)

35. Rücker B, Abreu-Vieira G, Bischoff LB, Harthmann AD, Sarkis JJF, Wink MR, Casali EA: The nucleotide hydrolysis is altered in blood serum of streptozotocin-induced diabetic rats. Arch. Physiol. Biochem. 116, 79-87 (2010)

36. Rüsing D, Müller CE, Verspohl EJ: The impact of adenosine and $\mathrm{A}_{2 \mathrm{~B}}$ receptors on glucose homoeostasis. J. Pharm. Pharmacol. 58, 1639-1645 (2006)

37. Salvatore CA, Jacobson MA, Taylor HE, Linden J, Johnson RG: Molecular cloning and characterization of the human A3 adenosine receptor. Proc. Natl. Acad. Sci. U. S. A. 90, 10365-10369 (1993)

38. Silveira LR, Alves AA, Denadai BS: Efeito da lipólise induzida pela cafeína na performance e no metabolismo de glicose durante o exercício intermitente (Effect of increased caffeine-induced lipolysis on performance and glucose metabolism during intermittent exercise). Rev. Bras. Ciência e Mov. 12, 21-26 (2004)

39. Skyler JS: Diabetes mellitus: pathogenesis and treatment strategies. J. Med. Chem. 47, 4113-4117 (2004)

40. Spyridopoulos I, Fichtlscherer S, Popp R, Toennes SW, Fisslthaler B, Trepels T, Zernecke A, Liehn EA, Weber C, Zeiher AM, Dimmeler S, Haendeler J: Caffeine enhances endothelial repair by an AMPK-dependent mechanism. Arterioscler. Thromb. Vasc. Biol. 28, 1967-1974 (2008)

41. Suh S-H, Paik I-Y, Jacobs K: Regulation of blood glucose homeostasis during prolonged exercise. Mol. Cells 23, 272-279 (2007)

42. Thong FSL, Derave W, Kiens B, Graham TE, Ursø B, Wojtaszewski JFP, Hansen BF, Richter EA: Caffeine-induced impairment of insulin action but not insulin signaling in human skeletal muscle is reduced by exercise. Diabetes 51, 583-590 (2002)

43. Tucker AL, Linden J: Cloned receptors and cardiovascular responses to adenosine. Cardiovasc. Res. 27, 62-67 (1993)

44. Van Soeren MH, Graham TE: Effect of caffeine on metabolism, exercise endurance, and catecholamine responses after withdrawal. J. Appl. Physiol. 85, 1493-1501 (1998)

45. Vendramini LC, Nishiura JL, Baxmann AC, Heilberg IP: Caffeine intake by patients with autosomal dominant polycystic kidney disease. Braz. J. Med. Biol. Res. 45, 834-840 (2012)

46. Wahren J, Ekberg K: Splanchnic regulation of glucose production. Annu. Rev. Nutr. 27, 329-345 (2007)

47. Watson JM, Jenkins EJ, Hamilton P, Lunt MJ, Kerr D: Influence of caffeine on the frequency and perception of hypoglycemia in free-living patients with type 1 diabetes. Diabetes Care 23, 455-459 (2000)

48. Yang D, Koupenova M, McCrann DJ, Kopeikina KJ, Kagan HM, Schreiber BM, Ravid K: The A2b adenosine receptor protects against vascular injury. Proc. Natl. Acad. Sci. U. S. A. 105, 792-796 (2008)

49. Yegutkin GG: Nucleotide- and nucleoside-converting ectoenzymes: important modulators of purinergic signalling cascade. Biochim. Biophys. Acta 1783, 673-694 (2008) 